Ethiopian Journal of Environmental Studies \& Management 7(5): 561 - 571, 2014

ISSN:1998-0507

doi: http://dx.doi.org/10.4314/ejesm.v7i5.9

Submitted: June 14, 2014

Accepted: September 09, 2014

\title{
ATTITUDES OF LOCAL RESIDENTS TOWARDS SUSTAINABLE ECOTOURISM DEVELOPMENT IN OLUMIRIN WATERFALL SOUTHWESTERN NIGERIA
}

*ADETOLA, B.O. AND ADEDIRAN, 0.R.

Department of Ecotourism and Wildlife Management, Federal University of Technology, Akure

\begin{abstract}
This paper investigates indigenous communities' attitudes towards sustainable ecotourism development in Olumirin Waterfall Southwestern Nigeria. A field survey via structured questionnaire was conducted on 150 village respondents living in the vicinity of Olumirin waterfall of which fifty questionnaires were randomly distributed to each of the three communities that were purposively selected. This is also complemented by observation during field survey. The data were analyzed using descriptive and inferential statistics. Result showed that awareness and knowledge of ecotourism was high in the communities. Majority (94\%) of the sampled population have positive attitude towards ecotourism activities in Olumirin waterfall, exhibit great appreciation of the existence of the waterfall and are interested in the continuity of the site as ecotourism attraction. Negative attitude have a minority perspective as tourists activities was not devoid of problems such as pollution, overcrowding and cultural diffusion. Gender $\left(\chi^{2}=14.11, p<0.05\right)$, Education $\left(\left(\chi^{2}=32.87, p<0.05\right)\right.$, and occupation $\left(\left(\chi^{2}=64.4\right.\right.$, $p<0.05)$, were significantly related to respondents perception of ecotourism development in Olumirin waterfall. Responses for positive attitude are larger as compared to the negative attitudes in the study site because the contribution of ecotourism activities towards economic enhancement of the rural people is high. However, effective regulation and proper planning is essential in order to enhance the sustainability of ecotourism in Olumirin waterfall while local people's active involvement at different level of ecotourism development is vital in ensuring its success.
\end{abstract}

Key Words: Local communities, waterfall, awareness, attitude, involvement, ecotourism

\section{Introduction}

Sustainable development promotes economic and social development in a way that avoids environmental degradation, over exploitation of natural resources or pollution (Greene, 2001). Responsible ecotourism however, includes programmes that minimize the negative aspects of conventional tourism on the environment and enhance the cultural integrity of local people. It differs from other forms of tourism particularly due to the opportunity for observation and learning it provides to tourists and its contribution to cultural conservation and long term sustainability of communities and natural resources (Campbell, 2002). Ecotourism is a term used to describe any form of tourism in natural surrounding that benefits the community, environment and local economy. The International Ecotourism Society (TIES, 1990) defines ecotourism as 'responsible travel to natural areas that conserves the environment and improves the well - being of the local people.

Ecotourism has become one of the fastest growing sectors of the tourism industry, 
growing annually at $10-50 \%$ worldwide, (Miller, 2007). It accounts for 20 percent of total international tourism. WTO forecast that, worldwide international tourists will increase from 613 million in 1997 to 1.6 billion by 2020 and earnings will jump from \$443 billion in 1997 to more than \$2 trillion by 2020 (WTO, 1991). Several African countries are set to cash in on this development, particularly ecotourism. Ecotourism is mainly the interaction between the physical environmental features for leisure purposes. It is in this light that several thousand of people leave their usual residence to areas with friendly climate, coastal regions for hiking and trekking, surfing and swimming and the enjoyment of friendly ambience. The added advantage of tourism over other industries is that the same product is sold over and over to different people, thus benefiting the community and the environment. Ecotourism advocates for a locally controlled tourism industry to ensure benefits to the local people and the sustainable use of resources (CeballosLascurain, 1996).

The involvement of local communities in ecotourism is one of its core precepts (Senko et al., 2011). Participation of these communities in ecotourism ventures has an ethical dimension, as local communities should benefit from such a relationship (Er, 2010; Weaver and Lawton, 2007; Azreen et al., 2011). To maximize the positive impacts of ecotourism, residents must be included in the planning and development of ecotourism projects in the early stages. In order for them to participate fully in the planning process, they must be aware of the impacts and be supportive of the development. Furthermore, it is important that local populations "have a basic level of awareness of the potential benefits and costs of tourism" to successfully participate in the planning process. Assessments of the awareness of ecotourism impacts can be measured by understanding the host community's perception of the positive and negative environmental, economical, and social impacts of ecotourism.

Ecotourism represents a viable economic alternative for local ecotourism destinations. They can participate directly in the operation of chalets, hotels, restaurants, and they often have practical local knowledge, which makes them effective nature guides once trained. Local community organizations can act as concessionaires of tourism services, with appropriate administrative training. Human development is much more than the expansion of socioeconomic income and wealth. Its focus must be people, and how they can conserve and make sustainable use of their environment, natural resources and ecosystems for sustainable meaningful roles in the development of their own. More children get to go to school, and people have access to better nutrition and healthcare facilities in the villages, as well as building of infrastructure for community interaction and for transportation Tourism actually has the capacity to improve rural and remote communities that do not have the access to all the opportunities that are available in larger cities. At the simplest level, just having tourists visit a community raises that community's awareness of the larger world outside their community. But there are several conditions that must be met for a local community to gain the maximum benefit from tourism. The first and foremost condition is that the local community wishes to be involved in the tourism that is going on. If a community does not want to participate, does not apply for any jobs or in any way seek an improvement in their situation, then it is very difficult for tourism to improve their conditions. Still, even in this situation, many benefits flow into this community from tourism. The improved infrastructure developed for the tourists, as well can be used by the locals. This includes better roads, 
improved water, electricity supplies and better waste disposal systems. Other benefits are increased business opportunities catering directly to the tourists; more job opportunities within the tourism sector and associated supporting jobs. This benefit the community in an additional way, as the young no longer has to leave the area to find work. Attainment of this notion of ecotourism being a financially viable tool that provides sustainable solution to economic challenges and conservation needs of local people, an alternative means of supporting rural economics to help revitalize and sustain local heritage is confounded by differences in perceptions about ecotourism development. Kayat (2002) suggested that residents' dependency on tourism industry would predict their attitude towards economic impacts from tourism development. This paper therefore investigates indigenous communities' attitudes towards sustainable ecotourism development in Olumirin Waterfall Southwestern Nigeria.

\section{Materials and Methods}

Osun state is is located in the southwestern part of Nigeria and covers an area of approximately $9,251 \mathrm{~km}^{2}$, lies between longitude $4^{\circ} 30^{\prime} 0^{\prime \prime} \mathrm{E}$ and $7^{\circ} 30^{\prime} 0^{\prime \prime} \mathrm{N}$ ((Wikipedia, 2014) (Figure 1). The state is bounded on the west by Oyo state, Ekiti state by the east, Kwara state, and in the south by the Ogun state. The state has a rich cultural heritage which shows in their music, art, dances, dresses and cultural festivals. They are well known for their talking drums and 'bata' music. They are also known for excellent works of art. There are seventeen documented tourist sites that can be developed to international standard to attract tourist from all over the world to the state. Olumirin waterfall is located in Erin- ijesa town, Oriade local government of Osun state and situated within latitude $7^{\circ} 30^{\prime}$ and $8^{\circ} 45^{\prime}$ North and longitude $4^{\circ} 31^{\prime}$ and $5^{\circ} 55^{\prime}$ East (Figure 2). The waterfall has a height of sixty metres with an assemblage of seven distinct cascades located on the southern slopes of the lush Effon ridge in Erin Ijesa town. The first cascade plummets through a narrow opening in a cluster of luxuriant tree trunks blanketed in dark green leafage, down a steeply folded rock face of about ten metres in height. Like a rain million limpid pins, the showers descend and inundate a huge boulder reposed at its plunge pool below. Fallen logs of wood laid in the pool and out flowing stream channel. The air hung muggy with a heavy smoke of plashed water droplets. The second cascade is the most gigantic of all, with the waters diving down a forty metres high cliff. The copious plunge is most spectacular in the rainy season when the stream channel is at flooding levels. It plunge pool forms shallow swimming pool for visitors at the site who are lucky and brave enough to get to the second fall. Climbing the waterfall is quite intimating and arduous as there are no steps constructed or clear paths made up of ridge slopes, except depressions and projections on the surface, as well as roots and branches of trees, forest climbers shrubs along the path which aid movements and serve as hand and foot holds when climbing. Nevertheless, the ascent of the enormous ridge is most rewarding as one is treated with dazzling and panoramic vistas of the surrounding landscape, depicting the true natural beauty of the Nigerian landmass (Naijatreks, 2011). 
Attitudes of Local Residents toward Sustainable Ecotourism.

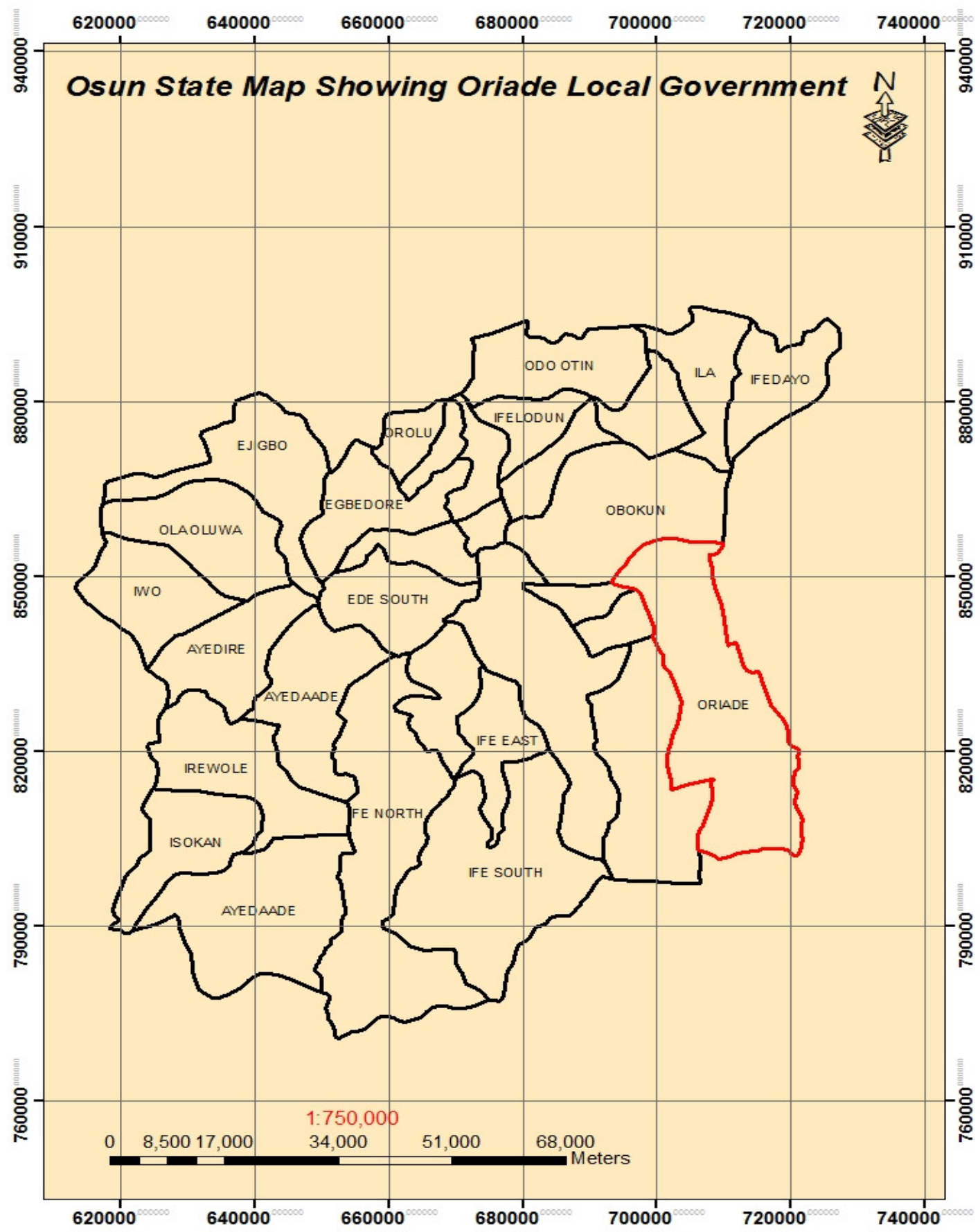

Figure 1: Map of Osun state showing Oriade local Government Area where Olumirin waterfall is located.

Source: Osun State Ministry of Land and Physical planning and Urban Development (2012) 


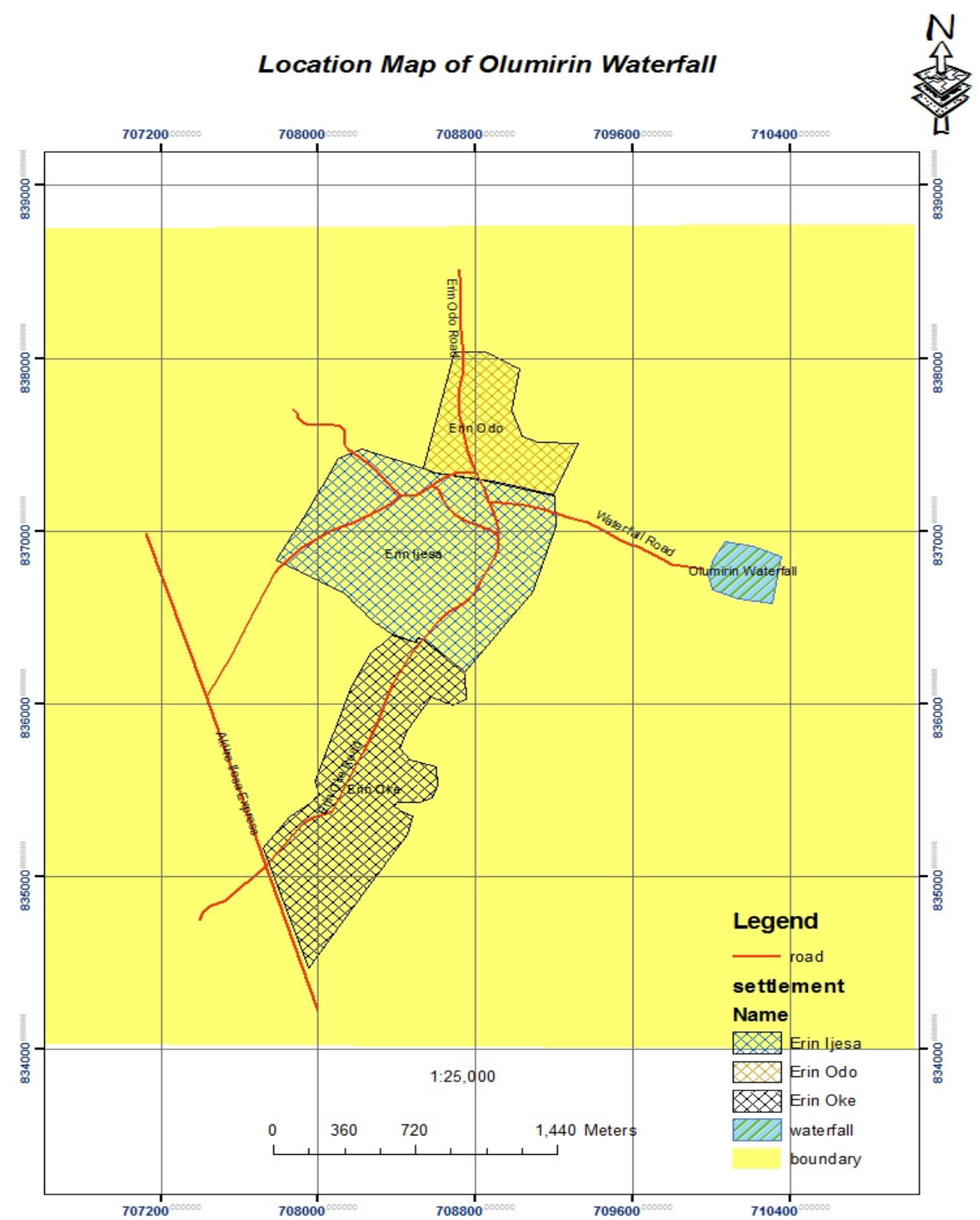

Figure 2: Map of Olumirin waterfall and its host communities.

\section{Methods of Data Collection}

A field survey via structured questionnaire was conducted on 150 village respondents living in the vicinity of Olumirin waterfall of which fifty questionnaires were randomly distributed to each of the three communities that were purposively selected. This is also complemented by observation during field survey. The data were analyzed using descriptive and inferential statistics (Ofem et al., 2012). Statistical Analysis

Socio demographic data of the respondents were subjected to descriptive analysis while inferential statistical analysis made use of Chi Square $\left(\chi^{2}\right)$ to test the relationship between demographic factors on 
respondents' perception toward sustainable ecotourism impact in Olumirin Waterfall.

\section{Result and Discussion}

The demographic characteristics of respondents' as shown in table 1 revealed that there were more male $(65 \%)$ than female (35\%) respondents. This is because males are easily accessible and willing to divulge required information as compared to females. Also, 24\%, 53\% and 23\% are between ages 20-40, 41-60 and greater than 60 years respectively out of which $72 \%$ are married, $34 \%$ had no formal education, while $66 \%$ have had primary $(20 \%)$, secondary $(30 \%)$, and tertiary $(16 \%)$ education. Livelihood activities varies among respondents with civil servant having the highest percentage $24 \%$, which was followed by petty trading (33\%) farmers and artisans (20\%), while hunter had the least $(3 \%)$. This is an indication that the respondents are matured, broad minded and in their active ages to judge rightly and give the result a balance of view. Majority of the respondents $(57 \%)$ have been living in the community from birth and were also able to provide necessary information since they have stayed in the community for a long period and are knowledgeable about the trend of development in Olumirin waterfall over the years.

The indigenous people's awareness of ecotourism development as presented in Figure 3 indicates that $96 \%$ of the respondents are aware that ecotourism is being developed in Olumirin Waterfall. The high level of awareness in the study area could be linked to continuous patronage of visitors to the waterfall and some developmental projects that is being undertaken by the state government towards boosting the image of the site. Moreover, $94 \%$ of the sampled population have positive attitude towards the continuity of ecotourism activities in Olumirin waterfall (Figure 4) as they exhibit great appreciation of the existence of the waterfall. The positive attitude is mainly due to transformation of the rural communities as a result of ecotourism impacts in the areas of infrastructural development $\quad 32.7 \%$, employment opportunities $(10.0 \%)$, increase in volume of trade $(20.0 \%)$, boost in tourists patronage which raises community's awareness of the larger world outside their community and popularity returns (23.3\%). This is in consonance with Horn et al. (2000) findings which showed that, Rotorua people were positive about tourism and felt that the industry had significant effect on them. Negative attitude have a minority perspective as tourists activities in Olumirin waterfall was not devoid of problems such as pollution $(6.0 \%)$, overcrowding $(3.3 \%)$ and cultural diffusion $(4.7 \%)$ as shown in Table 2 . The problem of waste is characterized by failure to dispose domestic waste following proper waste-disposal procedures while disposal of efflenent into the water creates the potential for contamination of drinking water supplies which agrees with DOT (2000) findings on environmental impacts of tourism development on the Okavango Delta, northwestern Botswana. Few of the respondents felt that tourism was eroding their traditional norms and culture and are being intimidated and disturbed by too many visitors at their local sites, these are the places they knew while growing up before they became international attractions and in-migration by non-locals has resulted in rapid social change within the communities this agrees with the findings of (Moisey, 2002). Improvement in the living condition of residents in the host communities occurred as a result of ecotourism development at the waterfall as high and moderate improvement were reported by $63.3 \%$ and $30.0 \%$ of the respondents respectively. Most (75.3\%) of them viewed ecotourism as very important, moderately important $(20.7 \%)$ while only $4.0 \%$ said ecotourism was not important. 
Responses for positive attitude are larger as compared to the negative attitudes towards the development of ecotourism in Olumirin waterfall which corroborate the findings of Andereck et al., (2005) that tourism industries can be a positive influence on the community's economy by resulting in effects such as economic diversity, jobs and tax revenue. Moreover, tourism is considered as a factor that contributes to a higher standard of living, able to give effect in terms of attracting investments and spending, which creates greater benefits than costs (Brida et al., 2011). Gender $\left(\chi^{2}=14.11, \quad \mathrm{p}<0.05\right)$, education $\left(\chi^{2}=32.87, \mathrm{p}<0.05\right)$, and occupation $\left(\chi^{2}=64.4, \quad \mathrm{p}<0.05\right), \quad$ have significant association with communities perception of ecotourism development in Olumirin waterfall (Table 3). This indicated that gender, occupation and education of respondents are the predictor of their attitudes towards sustainable ecotourism development in the waterfall. It is possible that education broadens people's perspective and perhaps, encourages greater awareness of the benefits of ecotourism. Williams et al. (2002) indicated that increased education often brings a greater awareness of wildlife and the environment.

\section{Conclusion}

Ecotourism has been identified as a catalyst for economic enhancement of the local communities adjourning Olumirin waterfall and its contributions towards improving the standard of living of the locals cannot be overemphasize. Therefore, as a pre-requisite to sustainable tourism development, local community involvement must be enhanced and facilitated by tourism developers and planners to give the host community a sense of ownership and control over the resources of the community while government should also develop measures and policies to address the negative issues identified in Olumirin waterfall.

\section{References}

Andereck, K.L., Valentine, K.M., Knopf, R.C. and Vogt, C.A. (2005). Residents' perceptions of community tourism impacts.Annals of Tourism Research, 32(4), 1056-1076.

Azreen, R.A., Chan, N.W. and Ahmad P.M. (2011). The Potentials and Perils of Ecotourism in Belum Temengor Forest Complex. World Applied Sciences Journal 12 (Special Issue of Tourism \& Hospitality): 01-09.

Brida, J.G., Osti, L. and Faccioli, M. (2011). Residents' perception and attitudes towards tourism impacts: a case study of the small rural community of Folgaria (Trentino-Italy). Benchmarking: An International Journal, 18(3): 359-385

Campbell, L.M. (2002). Ecotourism in rural developing communities. Annals of Tourism Research, 26(3): 534-553.

Ceballos-Lascurain, H. (1996). Tourism, Ecotourism and Protected Areas. Gland: IUCN Publication, 230pp.

Department of Tourism (DOT). (2000). Mobile Operator Task Force Report. Department of Tourism, Gaborone. 23 pp.

Er, A.C. (2010). The Nascent Development of Ecotourism in Lagong Hill. American Journal of Applied Science 7(12): 1528-1531.

Greene, O. (2001). Environmental Issues. Oxford University Press New York, pp 392- 405.

Horn, C., Simmons, D.G. and Fairweather, J.R. (2000). Evolving community response to tourism and change in Rotorua. Rotorua Case Study Report No 14/2000. Tourism Research and Education Centre, Lincoln University, Lincoln. $141 \mathrm{p}$.

Kayat, K. (2002). Power, social exchanges and tourism in Langkawi: rethinking resident perceptions. International 
Journal of Tourism Research, 4(3): 171-191.

Miller, F. (2007). Ecotourism Projects in Norway: Some Examples for Cold Climates in Global Ecotourism Conference", Norway, 14 - 16 May.

Moisey, R. (2002). The economics of tourism in national parks and protected areas. In Eagles, P.F.J.; McCool, S.F. (Eds): Tourism in national parks and protected areas: planning and management.CABI, Wallingford.

Naijatreks, (2011). The mysterious Waters of Oluminrin falls in Erin Ijesa. http://naijatreks.com/2011/04/olumirinwaterfalls/ retrieved on 12-06-2014

Ofem, O.O., Lifu, F.L., Ogar, I.J., Eja, E.I. and Ajadi, B.S. (2012). Potentials of Developing Cross River State National Park as a Tourist Resort. Academic Research International, 2: 549-555.

Osun State Ministry of Land and Physical Planning and Urban Development (2012). Osun state secretariat Osogbo, Osun state. http://osun.gov.ng/government/executiv e/ministries/lands-physical-planningand-urban-development/

Senko, J., Schneller, A.J., Solis, J., Ollervides, F. and Nichols, W.J. (2011).
People helping turtles, turtles helping people: Understanding resident attitudes towards sea turtle conservation and opportunities for enhanced community participation in Bahia Magdalena, Mexico. Ocean \& Coastal Management, 54(2): 148-157.

The International Ecotourism Society (TIES) (1990). Fact Sheet: Global Ecotourism. Available online at: http://www.box.net/shared/static/eauko njc0a.pdf (Accessed: March 27, 2012).

Weaver, D.B. and Lawton, L.J. (2007). Twenty years on: The state of contemporary ecotourism research. Tourism Management, 28(5): 11681179.

Wikipedia, (2014). Osun State, Nigeria. http://en.wikipedia.org/wiki/Osun_State . Accessed on 12-06-2014.

Williams, C.K., Ericsson, G. and Herberlein, T.A. (2002). A quantitative summary of attitude towards wolf and their reintroduction (1972-200). Wildlife Society Bulletin. 30: 575-584.

World Tourism Organization (1991). Tourism Trends WTO. (Brochure). Madrid. WTO (Publication). 
Table 1: Demographic characteristics of Respondents'

\begin{tabular}{llll}
\hline Demographic & Variables & Frequency & Percentages \\
\hline Gender & & & 65 \\
Total & Male & 98 & 35 \\
Age & Female & 52 & 100 \\
& & 150 & 24 \\
Total & $20-40$ & 36 & 53 \\
Marital Status & $41-60$ & 81 & 23 \\
& $>60$ & 34 & 100 \\
& & 150 & 14 \\
Total & Single & 21 & 72 \\
Education Level & Married & 108 & 2 \\
& Divorced & 3 & 12 \\
& Widowed & 18 & 100 \\
Total & No formal education & 150 & 34 \\
Occupation & Primary & 31 & 20 \\
& Secondary & 45 & 30 \\
& Tertiary & 24 & 16 \\
& & 150 & 100 \\
& Civil Servant & 36 & 24 \\
Total & Farmer & 30 & 20 \\
Length of stay & Hunter & 5 & 3 \\
& Trader & 49 & 33 \\
Total & Artisan & 30 & 20 \\
& & 150 & 100 \\
& $<30$ & 29 & 19 \\
& Fo & 36 & 24 \\
& & 85 & 57 \\
& & 150 & 100 \\
\hline & & &
\end{tabular}

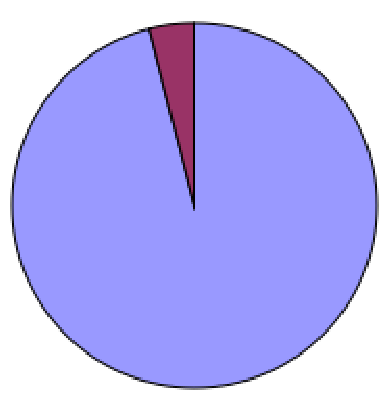

Figure 3: Respondents awareness of ecotourism in Olumirin Waterfall 


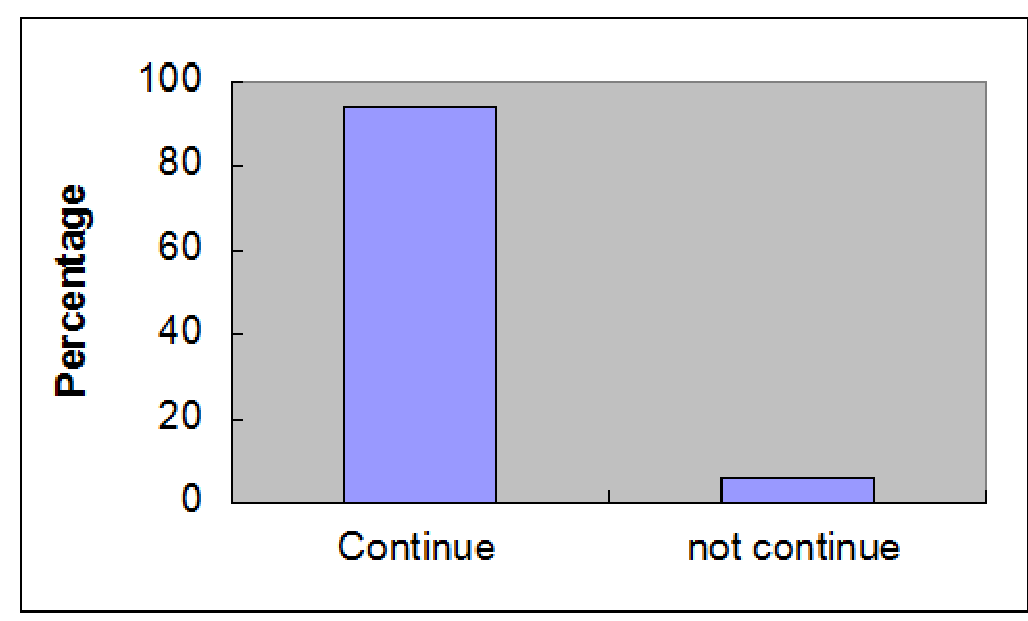

Figure 4: Respondents' interests in the continuity of Olumirin waterfall as ecotourism attraction site.

Table 2: Respondent views about ecotourism activities in Olumirin waterfall

\begin{tabular}{|c|c|c|c|}
\hline Respondents views & Variables & Frequency & Percentages \\
\hline \multirow{4}{*}{$\begin{array}{l}\text { Living condition in the } \\
\text { communities before } \\
\text { tourism was introduced }\end{array}$} & Poor & 79 & 52.7 \\
\hline & Fair & 54 & 36 \\
\hline & Good & 17 & 11.4 \\
\hline & Total & 150 & 100 \\
\hline \multirow{3}{*}{$\begin{array}{l}\text { Living condition in the } \\
\text { communities after } \\
\text { ecotourism has been } \\
\text { developed }\end{array}$} & Highly Improved & 95 & 63.3 \\
\hline & Moderately improved & 46 & 30.7 \\
\hline & No improvement & 9 & 6.0 \\
\hline Total & & 150 & 100 \\
\hline \multicolumn{4}{|l|}{ Ecotourism impacts } \\
\hline \multicolumn{4}{|l|}{ Positive } \\
\hline $\begin{array}{l}\text { Infrastructural } \\
\text { development }\end{array}$ & & 49 & 32.7 \\
\hline Employment opportunities & & 15 & 10.0 \\
\hline Increased volume of trade & & 30 & 20.0 \\
\hline \multicolumn{4}{|l|}{ recognition/popularity } \\
\hline \multicolumn{4}{|l|}{ Negative } \\
\hline Pollution & & 9 & 6.0 \\
\hline Overcrowding & & 5 & 3.3 \\
\hline Cultural diffusion & & 7 & 4.7 \\
\hline Total & & 150 & 100 \\
\hline \multirow{3}{*}{$\begin{array}{l}\text { Respondents opinion } \\
\text { about ecotourism activities } \\
\text { in Olumirin waterfall }\end{array}$} & Very important & $113(75.3 \%)$ & 75.3 \\
\hline & Moderately important & $31(20.7 \%)$ & 20.7 \\
\hline & Not important & $6(6.0 \%)$ & 6.0 \\
\hline Total & & 150 & 100 \\
\hline
\end{tabular}


Table $3 \mathrm{Chi}$-Square Test of association between respondents demographic characteristics and perception of ecotourism in Olumirin waterfall

\begin{tabular}{lllll}
\hline Variables & $\mathrm{X}^{2}$ Calculated & $\mathrm{df}$ & P-value & Remark \\
\hline Gender & 14.11 & 1 & 0.04 & $*$ \\
Age & 4.67 & 4 & 0.32 & $\mathrm{~ns}$ \\
Marital Status & 3.95 & 4 & 0.86 & $\mathrm{~ns}$ \\
Education & 32.87 & 4 & 0.00 & $*$ \\
Occupation & 64.4 & 5 & 0.00 & $*$ \\
\hline
\end{tabular}

$\mathrm{P}<0.05$

* $\quad$ significant

ns not significant 